\title{
ResearchArticle
}

\section{Study of heterosis for seed cotton yield, yield contributing and fibre quality traits in Desi cotton (Gossypeum arborium}

L.)

\author{
K.M. Lokesh, S.B. Borgaonkar, D.B. Deosarkar and V.N. Chinchane
}

\begin{abstract}
SUMMARY
Twenty four crosses were evaluated for average heterosis, heterobeltiosis and standard heterosis. The magnitude of heterosis, heterobeltiosis and standard heterosis were found significant for all the characters studied. The magnitude of heterosis, heterobeltiosis and standard heterosis for all the characters in the present study was highly appreciable. Out of twenty four crosses, the crosses showed highest and desirable significant standard heterosis for various traits viz., cross PA 832 x NDLA 3047 for days to 50 per cent flowering, for number of sympodia per plant and for number of bolls per plant; PA 778 x JLA 0716 for boll weight; PAIG 62 x CNA 1013 for days to maturity; PA 832 x ARBAS 1401 for $2.5 \%$ span length; PAIG 62 x CNA 1013 for fibre fineness (micronaire); PA 778 x JLA 0716 for fibre strength PA 832 x NDLA 3047 over standard check PKV Suvarna and PKVDH 1, respectively. The magnitude of average heterosis for plant height was 89.84 per cent in the cross combination PA 800 x CNA 1013. The cross PA 800 x CNA 1013 exhibited highest significant heterobeltiosis of 43.89 per cent. The cross PA 832 x NDLA 3047 displayed the highest significant positive heterosis over both standard check PKVDH 1 (13.83\%) and PKV Suvarna (53.52\%). The range of heterosis over check PKV Suvarna was -15.90 to 53.52 per cent. Three and eighteen crosses each recorded significant positive heterosis over standard check PKVDH 1, PKV Suvarna, respectively.
\end{abstract}

Key Words : Heterosis, Standard heterosis, Micronaire, Staple length, Heterobeltiosis

How to cite this article : Lokesh, K.M., Borgaonkar, S.B., Deosarkar, D.B. and Chinchane, V.N. (2018). Study of heterosis for seed cotton yield, yield contributing and fibre quality traits in Desi cotton (Gossypium arboreum L.). Internat. J. Plant Sci., 13 (1): 158-164, DOI: 10.15740/HAS/IJPS/13.1/158-164.

Article chronicle : Received : 27.07.2017; Revised : 05.12.2017; Accepted : 19.12.2017

\section{MEMBERS OF THE RESEARCH FORUM}

Author to be contacted :

S.B. Borgaonkar, Department of Agriculture Botany, College of Agriculture, Vasantrao Naik Marathwada Krishi Vidyapeeth, Parbhani (M.S.) India

Address of the Co-authors:

K.M. Lokesh, D.B. Deosarkar and V.N. Chinchane, Department of Agriculture Botany, College of Agriculture, Vasantrao Naik Marathwada Krishi Vidyapeeth, Parbhani (M.S.) India 